\title{
Correlation between Acne Awareness and Self-esteem during Adolescence
}

\author{
Ok-Sun Jang ${ }^{*}$, Anna Park \\ Department of Media Beauty Arts, Graduate School of Information Contents, Kwangwoon University, Seoul, Korea
}

\author{
*Corresponding author: Ok-Sun Jang, \\ Department of Media Beauty Arts, Graduate \\ School of Information Contents, Kwangwoon \\ University, 20 Kwangwoon-ro, Nowon-gu, \\ Seoul 01897, Korea \\ Fax: +8229405443 \\ Email: Ivbetn@naver.com
}

Received June 28, 2017

Revised November 3, 2017

Accepted November 30, 2017

Published June 30, 2018

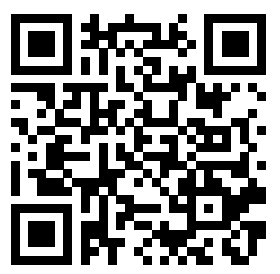

\begin{abstract}
Purpose: This study provided data on the necessity for education on skin beauty for adolescents through a correlation analysis of self-esteem according to acne recognition by examining the characteristics of the skin of adolescent girls with acne. Methods: A survey was conducted from December 1 to December 24, 2016, and analysis was performed using frequency analysis, crossover analysis, reliability analysis, one-way analysis of variance (ANOVA), and multiple regression analysis addressing a total of 396 responses. Results: The subjects of this study were elementary school students (16.4\%), middle school students (44.7\%), and high school students (38.9\%). Acne occurred in elementary school students (56.9\%), middle school students (82.5\%), and high school students (90.3\%). It occurred most frequently in the upper grades of elementary school students (37.0\%). The most common form of acne was comedos; however, the degree and extent of acne tended to increase in the upper grades. Acne awareness also tended to increase in the upper grades. Correlation analysis confirmed that the causes of acne, acne skin care, and acne-worsening factors were positively related to self-esteem. In addition, apart from the causes of acne, acne skin care and acne-worsening factors were found to have a positive effect on self-esteem $\left(p=0.000 ; R^{2}=0.032 ;\right.$ adj. $R^{2}=0.024$; acne skin care $\beta=0.650$; acne-worsening factors $\beta=0.620$ ). Conclusion: This study confirmed that becoming aware of the causes of acne, acne skin care, and acneworsening factors has a positive influence on adolescents. It is recommended that physiological education on skin care, such as the appropriate use of cosmetics and acne treatment, should be provided for adolescent girls who are experiencing physiological changes.
\end{abstract}

Keywords: Adolescent, Acne, Skin care, Acne awareness, Self-esteem

\section{Introduction}

시대를 불문하고 여성들이 미용에 대한 관심은 중요하게 여겨 지고 있다(Paek \& Kim, 2009). 더욱이 최근에는 생활수준이 향 상되고 아름다움에 대한 욕구가 증대됨에 따라 미용에 대한 관 심도 증가하였다. 미적인 욕망은 비단 여성에게만 국한되지 않 고 남성으로, 노인에서 어린 아이들까지도 중요하게 인식되고 있 다. 그러나 깨끗하고 아름다운 피부를 유지하고자 하는 욕구에 가장 큰 장애물이 되는 대표적인 피부질환 중 하나가 바로 여드 름이다(Kim \& Lee, 2009). 여드름은 비정상적으로 증가된 모낭 의 각화(Kim, 1995), 피지 분비의 증가(Shin et al., 2008), 피
지내 Propionibacterium acnes의 증식 및 염증의 유발로 주로 발생되지만(Lee \& Park, 1996), 다양한 원인으로 나타나고 면 포, 구진, 농포, 낭종 등 다양한 임상증상을 갖는다(Katsambas et al., 2004; Lee et al., 1996). 또한 여드름의 발생은 만성적 으로 반복되고 관리를 소홀히 하면 성인이 되고 난 후에도 지속 되거나 악화되어 사회생활을 하는데 있어 많은 이들을 고통스럽 게 하기도 한다(Oh \& $\mathrm{Heo}, 2008)$.

본 연구의 연구대상인 청소년기는 급격한 성장과 발달로 인한 신체적 성장과 정서적인 변화가 눈에 띄게 나타나는 단계로 생리 적인 변화가 심한 청소년기에 남성호르몬인 안드로겐(androgen) 의 영향으로 발생하는 것이 여드름이다(Park \& Dang, 2008). 
여드름은 10 대 사춘기 전후로 발병하기 시작하여 10 대 후반이나 20 대 초반에 이르러 자연적으로 소멸하는 것으로 알려져 있으나 일부는 중년까지도 지속되기도 한다(Goulden et al., 1999). 일 반적으로 남성보다 여성이 어린 나이에 먼저 나타나며, 남성이 증상이 더 심하고 빈도가 높게 나타나지만, 성인형 여드름은 여 성에게 더 흔한 것으로 알려져 있다(Kim \& Lee, 2009).

청소년기는 동성간의 관계보다 이성간의 관계가 중요하게 여 겨지는 시기인 만큼 외모에 그 어느 때보다 많은 관심을 가지 게 된다(Dang, 2013). 따라서, 여드름의 유-무 정도가 심리적 으로 민감한 청소년기의 학업 및 대인관계, 자아존중감 등에 좋 지 않은 영향을 미치는 것으로 보고된 바가 있다(Noh \& Jung, 2014). 또한 여드름은 여성이 남성보다, 유병 기간이 길수록, 많 은 종류의 병변이 있을수록(Ahn et al., 2005), 여드름으로 인 하여 정신적 영향을 받는다는 보고가 있는가 하면, 정신적인 스 트레스는 여드름을 일으키는 기전에 작용하는 심리적 요인이 되 고 이미 발생한 여드름을 악화시킬 수 있을 뿐만 아니라 분노, 불 안감 등 심리적 상태가 여드름의 경중도에 중요한 인자로 작용한 다는 보고도 있다(Kim \& Cha, 1999; Lee, 2006).

선행문헌은 대체로 고등학생 이상을 대상으로 이루어 졌으며 국내 피부과 문헌상 여드름에 대한 역학 연구는 대부분 병원에 내원한 여드름 환자를 대상으로 시행한 연구로 사춘기 여드름의 실제 유병율을 알기 힘들고, 일반적인 사춘기 여드름의 임상양상 이나 여드름 인식을 파악하는 데에는 한계가 있었다. 또한 여드 름의 상태가 자아존중감에 부정적인 영향을 주는 연구에 비해 여 드름으로 고민하는 청소년의 자아존중감을 향상을 위한 연구는 미비한 실적이다.

그 방안으로 본 연구에서는 청소년의 여드름 피부에 대한 인 식을 높여주면 여드름 발생시 관리 방법 및 악화 요인을 알고 대 처함으로써 자아존중감에 긍정적인 영향을 주는지를 알아보고자 한다.

따라서, 본 연구에서는 초등학생, 중학생 및 고등학생 전체 여 학생의 여드름 피부의 특성을 조사하여 청소년의 여드름 인식에 따른 자아존중감의 상관관계 분석을 통해 청소년을 대상으로 한 피부 미용 교육의 필요성에 대한 자료를 마련하는데 목적이 있 다.

\section{Methods}

\section{1. 연구대상 및 자료수집}

본 연구는 수도권 내 서울시, 화성시, 수원시에 거주하고 있는 초등학교 5-6학년, 중학교 1-3학년 및 고등학교 1-3학년의 여 학생을 대상으로 2016년 12월 1일부터 2016년 12월 24일까지 본 연구의 취지와 목적을 설명한 후 설문에 동의한 학생들을 연
구 대상자로 선정하여 설문지를 배포, 회수하였다. 총 420 부의 설문지가 회수되어 성실한 답변이 이루어진 총 396 부를 최종 분 석에 사용하였다.

\section{2. 연구도구}

연구 도구인 자가 응답형 설문지는 연구자가 문헌 고찰과 관 련하여 전문가와 상담을 통해 초안을 설계하였고, 통계 전문가의 자문을 거쳐 최종 완성하였다. 설문지의 구성은 연구 대상자의 인구학적 특성, 여드름 특성 및 여드름 인식도와 자아존중감 등 총 53 문항으로 구성하였다.

\section{3. 자료처리 및 분석방법}

본 연구의 자료처리 및 분석은 통계 패키지 Statistical Package for the Social Sciences (SPSS/WIN 23.0; IBM, USA)를 사용하였고, 유의 수준은 $p<0.05$ 로 설정하였다. 연구도 구인 설문지의 신뢰도 분석을 실시하여 Cronbach's alpha계수 는 0.6 이상으로 분석되었고, 연구 대상자의 인구학적 특성, 여 드름 특성 등은 빈도 분석 및 교차 분석을 실시하였다. 또한 여 드름 인식도와 자아존중감은 일원 배치 분산분석을 실시하고 사 후 검정으로는 Scheffe 검정을 실시하였고, 여드름 인식도가 자 아존중감에 미치는 영향을 알아보고자 다중회귀분석을 실시하였 다.

여드름 발생 종류와 피부 고민은 복수 응답 처리하였으며 통계 는 결측 값을 제외한 유효 퍼센트로 피부 유형 결측 $\mathrm{n}=1$ (응답률 $99.7 \%$ ), 여드름 인식도 $\mathrm{n}=1$ (응답률 $99.7 \%$ ), 자아존중감 $\mathrm{n}=14$ (응답률 $96.5 \%$ )이다.

\section{Results and Discussion}

\section{1. 연구 대상자의 일반적 특성}

연구 대상자의 일반적 특성은 Table 1 과 같다. 초등학생 $16.4 \%$ (65명), 중학생 $44.7 \%$ (177명), 고등학생 38.9\% (154 명)로 중학생과 고등학생이 대다수이다. 학년별로는 고등학 교 1학년 20.2\% (80명), 중학교 2학년 17.9\% (71명), 중학 교 1학년 $17.2 \%$ (68명), 고등학교 2학년 $15.4 \%$ (61명), 초 등 5 학년 $11.6 \%$ (46명) 순이며, 연구 대상자의 피부 유형은 복 합성 $(27.6 \%)$ 이 가장 많고, 건성(26.6\%), 중성(17.0\%), 지성 (13.7\%), 잘 모르겠다(10.6\%), 민감성(4.6\%) 순으로 복합성과 건성의 피부 유형이 과반 이상이었다.

\section{2. 여드름 발생 여부 및 발생 시기}

Table 2 는 연구 대상자의 여드름 유병율로 초등학교 $56.9 \%$ (37명), 중학교 82.5\% (146명), 고등학교 90.3\% (139명) (전체 
Table 1. Demographic characteristics of the subjects

\begin{tabular}{|c|c|c|c|}
\hline Division & & $\mathrm{N}$ & $\%$ \\
\hline \multirow{3}{*}{ Level of school } & Elementary school & 65 & 16.4 \\
\hline & Middle school & 177 & 44.7 \\
\hline & High school & 154 & 38.9 \\
\hline \multirow{8}{*}{ Grade } & 5th grade, elementary school & 46 & 11.6 \\
\hline & 6 th grade, elementary school & 19 & 4.8 \\
\hline & 1st grade, middle school & 68 & 17.2 \\
\hline & 2nd grade, middle school & 71 & 17.9 \\
\hline & 3rd grade, middle school & 38 & 9.6 \\
\hline & 1st grade, high school & 80 & 20.2 \\
\hline & 2nd grade, high school & 61 & 15.4 \\
\hline & 3rd grade, high school & 13 & 3.3 \\
\hline \multirow{6}{*}{ Skin type } & Dry & 105 & 26.6 \\
\hline & Normal & 67 & 17.0 \\
\hline & Oily & 54 & 13.7 \\
\hline & Complex & 109 & 27.6 \\
\hline & Sensitive & 18 & 4.6 \\
\hline & Do not know & 42 & 10.6 \\
\hline
\end{tabular}

Missing values, skin type $(n=1)$.

평균 81.3\%)로 나타났으며 학년이 증가할수록 여드름 발생 비 율이 높아지는 것으로 나타났다. 또한 피부 유형에 따른 여드 름 발생 차이 분석 결과 복합성과 지성의 피부 유형이 여드름 발 생 비율이 가장 높고(96.3\%) 다음으로는 건성(80.0\%)과 민감성 (77.8\%)의 여드름 발생율이 높게 나타났다.

일본 카가와 현의 $13-19$ 세 1,443 명을 대상으로 한 Kubota (2010)의 연구에서 59.5\%가 여드름이 있다고 했으며(남학생의 $51.6 \%$, 여학생의 $64.8 \%$ ), 중국 광둥성의 주하이 지역 10-18세 3,163 명을 대상으로 한 연구(Wu et al., 2007)에서는 여드름 유
병율이 $53.5 \%$ 였고 남성은 $51.3 \%$, 여성은 $58.6 \%$ 였다. 프랑스 의 12-25세 852명을 대상으로 한 연구(Poli et al., 2011)에서 는 $66.2 \%$ 가 여드름을 경험한 것으로 나타나 여드름이 전 세계적 청소년의 피부질환임을 확인할 수 있었다.

국내 문헌의 경우 충청지역 남녀 청소년을 대상으로 연구한 Won (2009)은 여드름 유병율 79.9\%로 연령이 증가할수록 여드름 유병 율이 높아지는 연구 결과를 보고하여 본 연구의 전체 평균 $81.3 \%$ 및 학교 급과 정적 상관관계를 보여 유사한 결과로 나타났다. 또한 한국인 청소년 여드름을 연구한 Shin (1973)에서 여드름 유병

Table 2. Acne occurrence

(Units: persons, \%)

\begin{tabular}{|c|c|c|c|c|c|}
\hline \multirow{2}{*}{ Division } & & \multicolumn{2}{|c|}{ Acne occurrence } & \multirow{2}{*}{$x^{2}$} & \multirow{2}{*}{$p$} \\
\hline & & Present & Absent & & \\
\hline \multirow{4}{*}{ Level of school } & Elementary school & 37 (56.9\%) & 28 (43.1\%) & \multirow{4}{*}{36.123} & \multirow{4}{*}{$0.000^{* * *}$} \\
\hline & Middle school & $146(82.5 \%)$ & $31(17.5 \%)$ & & \\
\hline & High school & 139 (90.3\%) & 15 (9.7\%) & & \\
\hline & Sum & $322(81.3 \%)$ & $74(18.7 \%)$ & & \\
\hline \multirow{6}{*}{ Skin type } & Dry & $84(80.0 \%)$ & $21(20.0 \%)$ & \multirow{6}{*}{55.286} & \multirow{6}{*}{$0.000^{* * *}$} \\
\hline & Normal & $41(61.2 \%)$ & $26(38.8 \%)$ & & \\
\hline & Oily & $52(96.3 \%)$ & $2(3.7 \%)$ & & \\
\hline & Complex & $105(96.3 \%)$ & $4(3.7 \%)$ & & \\
\hline & Sensitive & $14(77.8 \%)$ & $4(22.2 \%)$ & & \\
\hline & Do not know & 25 (59.5\%) & 17 (40.5\%) & & \\
\hline
\end{tabular}

${ }^{* * *} p<0.001 ;$ Missing values, skin type $(n=1)$. 
Table 3. Time of acne occurrence

\begin{tabular}{|c|c|c|c|}
\hline Division & & $\mathrm{N}$ & $\%$ \\
\hline \multirow{3}{*}{ When } & Elementary school & 120 & 37.3 \\
\hline & Middle school & 169 & 52.5 \\
\hline & High school & 33 & 10.2 \\
\hline \multirow{7}{*}{ Grade } & Elementary school lower grades & 1 & 0.3 \\
\hline & Elementary school upper grades & 119 & 37.0 \\
\hline & 1st grade, middle school & 85 & 26.4 \\
\hline & 2nd grade, middle school & 54 & 16.8 \\
\hline & 3rd grade, middle school & 30 & 9.3 \\
\hline & 1st grade, high school & 29 & 9.0 \\
\hline & 2nd grade, high school & 4 & 1.2 \\
\hline
\end{tabular}

율은 남성 $63.6 \%$, 여성 $33.6 \%$ 로 나타났고, Kim \& Cha (2000) 는 중 · 고 남녀 학생의 $74.8 \%$, Oh \& Heo (2008)에서는 $77.8 \%$ 로 나타났다. 이는 연구 대상에 따라 유병율에 차이는 있으나 현 재로 올수록 조금씩 높아지는 경향을 보이고 있다. Kim \& Lee (2009)의 연구에서 남녀 고등학생은 자신의 피부 유형을 지성 피 부로 응답한 비율이 가장 높았고 다음으로 정상 피부, 건성 피 부, 복합성 피부 순으로 나타나 본 연구와 다소 차이가 나타났으 나 연구 대상의 성별, 연령, 지식 정도가 다르기 때문으로 판단 된다.

본 연구에서 피부 유형에 따른 여드름 발생 차이로는 지성과 복합성 피부의 유형이 가장 높게 나타났으나, 상대적으로 건성과 민감성의 피부 유형도 여드름 유병율을 무시할 수 없는 수치이므 로 저자극 여드름 화장품 사용과 보습 관리 등에 신경을 써야 할 것으로 사료된다. 아울러 본 연구가 피지 분비량을 객관적인 척 도나 기구로 측정한 것이 아니기 때문에 객관화하기에는 다소 무 리가 있지만, 피지 분비와 여드름의 관련성을 어느 정도 짐작해 볼 수 있다.

여드름 발생 시기에 대한 빈도 분석 결과는 Table 3 과 같다. 발생 시기의 경우 초등학교 $37.3 \%$ (120명), 중학교 $52.5 \%$ (169 명), 고등학교 $10.2 \%$ (33명)로 나타났으며, 발생 학년으로는 초 등학교 고학년 $37.0 \%$ (119명)이 가장 높고 다음으로 중학교 1 학년 $26.4 \%$ (85명), 중학교 2학년 $16.8 \%$ (54명), 중학교 3학년 9.3\% (30명), 고등학교 1학년 9.0\% (29명)순으로 조사되었다. 즉, 발생 시점은 초등학교 고학년에서 정점이며 중학교를 지나면 서 낮아지는 것으로 이 시기에 청소년들이 여드름 관리와 올바른 지식을 갖고 대처할 수 있도록 이들에게 정보를 제공해야 할 것 으로 사료된다.

Shin (1973)의 연구에서 여드름의 초발 연령이 14-15세가 가장 높게 나타났으나 본 연구에서는 초등학교 고학년 5-6학년 인 12-13세가 가장 높아 과거에 비해 여드름 초발 연령이 빨라 지고 있는 것으로 나타났다. 한편 Shin et al. (2009)의 연구에
서 서울 성동 지역 여자 중학생의 2004년도 여드름의 평균 초발 연령은 12.40 세로 나타나 본 연구의 초등학교 고학년 시기에 발 생하는 점과 유사하게 나타났다.

\section{3. 여드름 발생 종류}

재학 학교에 따른 여드름 발생 종류는 Table 4 와 같다. 본 연 구의 여드름 등급은 얼굴에 주로 많이 나타나는 여드름 종류로 1 등급-면포, 2 등급-구진, 3 등급-농포, 4 등급-결절이다. 본 연 구에서 청소년들은 전반적으로 면포의 여드름 종류가 많은 것으 로(초등학생 $67.6 \%$, 중학생 $60.3 \%$, 고등학생 $56.1 \%$ ) 나타났으 나, 중학교 이상부터는 구진의 비율이 중학교 $31.5 \%$, 고등학교 $30.9 \%$ 로 초등학교 $18.9 \%$ 보다 높아지는 것으로 나타났으며, 고 등학교의 경우 결절의 비율(18.0\%) 또한 초등학교, 중학교 보다 높은 것으로 나타나 재학 학교가 높아지면 여드름 등급도 높아지 는 것으로 나타났다. 피부 유형별로는 건성, 중성, 복합성, 민감 성의 피부 유형의 경우는 면포의 여드름 종류가 많았으며, 지성 은 구진의 여드름 종류가 많은 것으로 나타났다.

이는 Shin et al. (2009)이 중학생을 대상으로 지성일수록 한 국형 여드름 중증도 시스템(Korean Acne Grading System, KAGS) 등급이 높은 경향을 보였으며, Won (2009)의 연구에 서 2 등급과 3 등급 여드름의 경우 학교 급에 따라 등급이 증가 $(p<0.001)$ 하는 것으로 나타나, 본 연구에서 재학 학교에 따라 여드름 등급이 올라가는 결과와 유사하다. Kim \& Cha (2000) 는 남녀 중고생의 대부분이 구진과 농포가 약간 있는 경한 등급 (74.3\%)으로 나타났고, Ham et al. (2009)에서 남녀 고등학생 의 면포성 여드름의 비율이 $41.9 \%$ 로 가장 높고 다음이 면포와 구진(27.4\%)으로 경미한 여드름이 주로 발생하는 것으로, 본 연 구에서 나타난 연구결과와 유사하다. 또한 남녀 중학생을 대상으 로 연구한 Na et al. (2009)는 초기형 여드름이 80\%, 후기형 여 드름이 $20 \%$ 로 나타나 본 연구와 같이 대부분의 청소년이 경미한 여드름이라는 것을 보여준다. 
Table 4. Types of acne occurrence

\begin{tabular}{|c|c|c|c|c|c|c|c|}
\hline \multirow{2}{*}{ Division } & & \multicolumn{4}{|c|}{ Acne type } & \multirow{2}{*}{$x^{2}$} & \multirow{2}{*}{$p$} \\
\hline & & Comedo & Papule & Pustule & Nodule & & \\
\hline \multirow{3}{*}{$\begin{array}{l}\text { Level of } \\
\text { school }\end{array}$} & Elementary school & $25(67.6 \%)$ & $7(18.9 \%)$ & $5(13.5 \%)$ & $1(2.7 \%)$ & \multirow{3}{*}{18.995} & \multirow{3}{*}{$0.015^{*}$} \\
\hline & Middle school & $88(60.3 \%)$ & $46(31.5 \%)$ & $20(13.7 \%)$ & $8(5.5 \%)$ & & \\
\hline & High school & 78 (56.1\%) & 43 (30.9\%) & $22(15.8 \%)$ & 25 (18.0\%) & & \\
\hline \multirow{6}{*}{ Skin type } & Dry & $56(66.7 \%)$ & $21(25.0 \%)$ & $6(7.1 \%)$ & $12(14.3 \%)$ & \multirow{6}{*}{45.774} & \multirow{6}{*}{$0.001^{* * *}$} \\
\hline & Normal & $28(68.3 \%)$ & $9(22.0 \%)$ & $2(4.9 \%)$ & $3(7.3 \%)$ & & \\
\hline & Oily & $22(42.3 \%)$ & $23(44.2 \%)$ & $10(19.2 \%)$ & 7 (13.5\%) & & \\
\hline & Complex & $65(62.5 \%)$ & $32(30.8 \%)$ & $20(19.2 \%)$ & $7(6.7 \%)$ & & \\
\hline & Sensitive & $6(42.9 \%)$ & $4(28.6 \%)$ & $3(21.4 \%)$ & $5(35.7 \%)$ & & \\
\hline & Do not know & $14(56.0 \%)$ & 7 (28.0\%) & $5(20.0 \%)$ & $0(0.0 \%)$ & & \\
\hline
\end{tabular}

Comedo, grade 1; Papule, grade 2; Pustule, grade 3; Nodule, grade 4.

Multiple response processing.

${ }^{*} p<0.05 ;{ }^{* *} p<0.001$; Missing values, skin type $(n=1)$.

Table 5. Current facial skin condition

\begin{tabular}{|c|c|c|c|c|c|c|c|}
\hline \multirow[b]{2}{*}{ Division } & & \multicolumn{4}{|c|}{ Current facial skin condition } & \multirow[b]{2}{*}{$x^{2}$} & \multirow[b]{2}{*}{$p$} \\
\hline & & $\begin{array}{c}\text { Clean skin } \\
\text { without acne }\end{array}$ & $\begin{array}{l}\text { Some acne } \\
\text { remains }\end{array}$ & $\begin{array}{c}\text { More than half } \\
\text { of the face } \\
\text { has acne }\end{array}$ & $\begin{array}{l}\text { Acne all over } \\
\text { the face }\end{array}$ & & \\
\hline \multirow{3}{*}{$\begin{array}{l}\text { Level of } \\
\text { school }\end{array}$} & Elementary school & $9(24.3 \%)$ & $26(70.3 \%)$ & $2(5.4 \%)$ & $0(0.0 \%)$ & \multirow{3}{*}{13.955} & \multirow{3}{*}{$0.030^{*}$} \\
\hline & Middle school & $40(27.4 \%)$ & $89(61.0 \%)$ & $13(8.9 \%)$ & $4(2.7 \%)$ & & \\
\hline & High school & $20(14.5 \%)$ & $94(68.1 \%)$ & $23(16.7 \%)$ & $1(0.7 \%)$ & & \\
\hline \multirow{6}{*}{ Skin type } & Dry & $22(26.2 \%)$ & $58(69.0 \%)$ & $4(4.8 \%)$ & $0(0.0 \%)$ & \multirow{6}{*}{32.556} & \multirow{6}{*}{$0.005^{* *}$} \\
\hline & Normal & $14(34.1 \%)$ & $26(63.4 \%)$ & $1(2.4 \%)$ & $0(0.0 \%)$ & & \\
\hline & Oily & $5(9.6 \%)$ & $31(59.6 \%)$ & $14(26.9 \%)$ & $2(3.8 \%)$ & & \\
\hline & Complex & $18(17.3 \%)$ & $70(67.3 \%)$ & $13(12.5 \%)$ & $3(2.9 \%)$ & & \\
\hline & Sensitive & $3(21.4 \%)$ & $8(57.1 \%)$ & $3(21.4 \%)$ & $0(0.0 \%)$ & & \\
\hline & Do not know & $7(28.0 \%)$ & $15(60.0 \%)$ & $3(12.0 \%)$ & $0(0.0 \%)$ & & \\
\hline
\end{tabular}

${ }^{*} p<0.05 ;{ }^{* * *} p<0.001 ;$ Missing values, skin type $(\mathrm{n}=1)$.

그러나 청소년과 성인 여드름 환자를 대상으로 연구한 Kang $\& \mathrm{Hahm}$ (2000)의 연구에 따르면 여드름 중증도는 성인기에 비 해 청소년기에 더 심하게 나타나는 것으로 조사되었다. 병원에 내 원한 여드름 환자를 대상으로 한 Lee et al. (1996)의 연구를 보 면 경한 등급 $45 \%$, 보통 $46.2 \%$, 심한 등급 $8.8 \%$ 이었으나, 전체 환자 중 $60 \%$ 는 여드름으로 인하여 대인 관계에 지장을 받는다 고 응답하였으며 $20.5 \%$ 는 매우 지장을 받는다고 하여 개인이 느 끼는 중증도가 심하다는 것을 알 수 있었다. 아울러 Kim \& Cha (1999)의 연구에서 여드름 상태가 심할수록 자아존중감이 낮아지 는 것으로 나타났으므로 청소년기의 여드름이 경미하다고 무시할 수는 없는 사항이다. 따라서 청소년기 여드름의 진행이 더 악화되 지 않도록 피부 관리에 주의가 필요하며 치료적 수단과 관리 방법 에 대한 지식을 제공해야 할 필요성이 있는 것으로 사료된다.

\section{4. 현재 얼굴의 피부 상태 및 고민}

재학 학교에 따른 현재 얼굴의 피부상태 분석 결과는 Table 5 와 같다. 대부분 현재 얼굴에 여드름이 일부 남아 있음이라고 응 답한 비율이 가장 높게(초등학교 $70.3 \%$, 중학교 $61.0 \%$, 고등학 교 68.1\%) 나타났으나, 중학교의 경우 깨끗한 피부를 유지한다 는 비율도(27.4\%) 초등학교나 고등학교에 비해 상대적으로 높 게 나타났으며, 고등학교의 경우 여드름이 얼굴 절반 이상 남 아 있다는 비율도 $16.7 \%$ 로 초등학교 $(5.4 \%)$, 중학교 $(8.9 \%)$ 에 비 해 높게 나타났다. 피부 유형에 따른 차이 분석 결과, 대부분 여 드름이 일부 남아 있는 정도의 비율이 가장 높았으나 건성, 중성 과 복합성의 경우 여드름이 없어지고 깨끗한 피부를 유지한다는 비율도 높았으며, 얼굴 절반 이상에 여드름이 남아 있다는 비율 이 가장 높은 피부 유형은 지성(26.9\%), 민감성(21.4\%), 복합성 $(12.5 \%)$ 순으로 나타났다. 
Table 6. Worries about facial skin

\begin{tabular}{|c|c|c|c|c|c|c|c|c|c|c|c|}
\hline \multirow{2}{*}{ Division } & & \multicolumn{8}{|c|}{ Worries about facial skin } & \multirow{2}{*}{$x^{2}$} & \multirow{2}{*}{$p$} \\
\hline & & Oil & Acne & Dry & Corneous & Pore & Freckles & None & Etc. & & \\
\hline \multirow{3}{*}{$\begin{array}{l}\text { Level of } \\
\text { school }\end{array}$} & $\begin{array}{l}\text { Elementary } \\
\text { school }\end{array}$ & $\begin{array}{c}2 \\
(3.1 \%)\end{array}$ & $\begin{array}{c}20 \\
(30.8 \%)\end{array}$ & $\begin{array}{c}5 \\
(7.7 \%)\end{array}$ & $\begin{array}{c}1 \\
(1.5 \%)\end{array}$ & $\begin{array}{c}9 \\
(13.8 \%)\end{array}$ & $\begin{array}{c}6 \\
(9.2 \%)\end{array}$ & $\begin{array}{c}23 \\
(35.4 \%)\end{array}$ & $\begin{array}{c}1 \\
(1.5 \%)\end{array}$ & \multirow{3}{*}{91.22} & \multirow{3}{*}{$0.000^{* * *}$} \\
\hline & $\begin{array}{l}\text { Middle } \\
\text { school }\end{array}$ & $\begin{array}{c}25 \\
(14.1 \%)\end{array}$ & $\begin{array}{c}68 \\
(38.4 \%)\end{array}$ & $\begin{array}{c}29 \\
(16.4 \%)\end{array}$ & $\begin{array}{c}18 \\
(10.5 \%)\end{array}$ & $\begin{array}{c}34 \\
(19.2 \%)\end{array}$ & $\begin{array}{l}15 \\
(8.5 \%)\end{array}$ & $\begin{array}{l}10 \\
(5.6 \%)\end{array}$ & $\begin{array}{c}4 \\
(2.3 \%)\end{array}$ & & \\
\hline & High school & $\begin{array}{c}25 \\
(16.2 \%)\end{array}$ & $\begin{array}{c}73 \\
(47.4 \%)\end{array}$ & $\begin{array}{c}16 \\
(10.4 \%)\end{array}$ & $\begin{array}{l}11 \\
(7.1 \%)\end{array}$ & $\begin{array}{c}49 \\
(31.8 \%)\end{array}$ & $\begin{array}{l}12 \\
(7.8 \%)\end{array}$ & $\begin{array}{c}6 \\
(3.9 \%)\end{array}$ & $\begin{array}{c}3 \\
(1.9 \%)\end{array}$ & & \\
\hline \multirow{6}{*}{$\begin{array}{l}\text { Skin } \\
\text { type }\end{array}$} & Dry & $\begin{array}{c}3 \\
(2.9 \%)\end{array}$ & $\begin{array}{c}40 \\
(38.1 \%)\end{array}$ & $\begin{array}{c}36 \\
(34.3 \%)\end{array}$ & $\begin{array}{c}12 \\
(11.4 \%)\end{array}$ & $\begin{array}{c}20 \\
(19.0 \%)\end{array}$ & $\begin{array}{c}5 \\
(4.8 \%)\end{array}$ & $\begin{array}{c}3 \\
(2.9 \%)\end{array}$ & $\begin{array}{c}4 \\
(3.8 \%)\end{array}$ & \multirow{6}{*}{210.64} & \multirow{6}{*}{$0.000^{* * *}$} \\
\hline & Normal & $\begin{array}{c}5 \\
(7.5 \%)\end{array}$ & $\begin{array}{c}20 \\
(29.9 \%)\end{array}$ & $\begin{array}{c}2 \\
(3.0 \%)\end{array}$ & $\begin{array}{c}2 \\
(3.0 \%)\end{array}$ & $\begin{array}{c}9 \\
(13.4 \%)\end{array}$ & $\begin{array}{c}10 \\
(14.9 \%)\end{array}$ & $\begin{array}{c}20 \\
(29.9 \%)\end{array}$ & $\begin{array}{c}2 \\
(3.0 \%)\end{array}$ & & \\
\hline & Oily & $\begin{array}{c}13 \\
(24.1 \%)\end{array}$ & $\begin{array}{c}31 \\
(57.4 \%)\end{array}$ & $\begin{array}{c}3 \\
(5.6 \%)\end{array}$ & $\begin{array}{c}6 \\
(11.1 \%)\end{array}$ & $\begin{array}{c}15 \\
(27.8 \%)\end{array}$ & $\begin{array}{c}2 \\
(3.7 \%)\end{array}$ & $\begin{array}{c}2 \\
(3.7 \%)\end{array}$ & $\begin{array}{c}1 \\
(1.9 \%)\end{array}$ & & \\
\hline & Complex & $\begin{array}{c}24 \\
(22.2 \%)\end{array}$ & $\begin{array}{c}52 \\
(48.1 \%)\end{array}$ & $\begin{array}{c}5 \\
(4.6 \%)\end{array}$ & $\begin{array}{c}5 \\
(4.6 \%)\end{array}$ & $\begin{array}{c}38 \\
(35.2 \%)\end{array}$ & $\begin{array}{l}10 \\
(9.3 \%)\end{array}$ & $\begin{array}{c}0 \\
(0.0 \%)\end{array}$ & $\begin{array}{c}1 \\
(0.9 \%)\end{array}$ & & \\
\hline & Sensitive & $\begin{array}{c}3 \\
(16.7 \%)\end{array}$ & $\begin{array}{c}6 \\
(33.3 \%)\end{array}$ & $\begin{array}{c}2 \\
(11.1 \%)\end{array}$ & $\begin{array}{c}3 \\
(16.7 \%)\end{array}$ & $\begin{array}{c}4 \\
(22.2 \%)\end{array}$ & $\begin{array}{c}2 \\
(11.1 \%)\end{array}$ & $\begin{array}{c}1 \\
(5.6 \%)\end{array}$ & $\begin{array}{c}0 \\
(0.0 \%)\end{array}$ & & \\
\hline & Do not know & $\begin{array}{c}3 \\
(7.1 \%)\end{array}$ & $\begin{array}{c}12 \\
(28.6 \%)\end{array}$ & $\begin{array}{c}2 \\
(4.8 \%)\end{array}$ & $\begin{array}{c}2 \\
(4.8 \%)\end{array}$ & $\begin{array}{c}6 \\
(14.3 \%)\end{array}$ & $\begin{array}{c}4 \\
(9.5 \%)\end{array}$ & $\begin{array}{c}13 \\
(31.0 \%)\end{array}$ & $\begin{array}{c}0 \\
(0.0 \%)\end{array}$ & & \\
\hline
\end{tabular}

Multiple response processing.

${ }^{* * *} p<0.001$; Missing values, skin type $(n=1)$.

이는 Won (2009)의 연구에서 청소년의 여드름은 2 등급과 3 등급이 많이 나타났고, Oh \& Heo (2008)은 여드름 발생 부위 로 가장 많은 것은 이마와 코 등 얼굴의 특정 부위인 경우로서 전 체의 $66.3 \%$ 를 차지하는 것으로 나타났다. 이상의 선행연구와 본 연구를 통해 청소년의 여드름이 특정 일부분에 주로 나타나고 학 년이 증가할수록 범위도 넓어지는 것을 알 수 있었다. 또한 Kim $\&$ Lee (2009)에서 남녀 고등학생은 여드름 증상에 대한 인식에 서 현재 여드름 증상이 있고(89.3\%) 증상이 심하다고 응답한 학 생은 $88.0 \%$ 로, 본 연구 Table 4 및 선행연구 결과 대부분이 경 한 여드름 등급이지만 청소년 본인이 느끼는 주관적인 등급은 높 다는 것을 알 수 있다.

아울러 중학교의 경우 깨끗한 피부를 유지한다는 비율도 초등 학교나 고등학교에 비해 높게 나타났는데 이는 여드름이 여성의 경우 초경을 전 · 후하여 발생하여 여드름이 일시적으로 생겼다 가 사라졌을 것으로 여겨진다.

또한 본 연구에서 연구 대상자의 얼굴 부문 피부 고민은 Table 6에 나타내었다. 대부분 여드름이 가장 높은 것(초등학 교 $30.8 \%$, 중학교 $38.4 \%$, 고등학교 $47.4 \%$ )으로 나타났다. 다 만, 학년이 올라갈수록 모공(초등학교 $13.8 \%$, 중학교 $19.2 \%$, 고등학교 $31.8 \%$ ) 및 유분(초등학교 $3.1 \%$, 중학교 $14.1 \%$, 고 등학교 $16.2 \%)$ 등의 피부에 대한 고민도 증가하는 것으로 조사
되었다. 피부 유형에 따라서 얼굴 부분의 피부 고민으로는 모 든 피부 유형에서 역시 여드름을 선택하였으며 건성의 경우 건 조함(34.3\%), 지성의 경우 모공(27.8\%), 복합성의 경우도 모공 $(35.2 \%)$ 이 여드름 다음으로 고민인 것으로 나타났다.

\section{5. 여드름 인식도와 자아존중감 분석}

청소년의 여드름 인식도와 자아존중감의 상관관계를 알아보고 자 일원배치 분산 분석을 실시하고 사후 검정으로는 Scheffe 검 정을 실시하였다. 또한 여드름 인식도가 자아존중감에 미치는 영 향을 알아보고자 다중 회귀 분석을 하였다.

재학 학교에 따른 여드름 인식도와 자아존중감에 대한 분석 결 과, 자아존중감을 제외 한 여드름 인식도에는 통계적으로 차이가 있는 것으로 나타났다(Table 7). 여드름 인식도는 평균 69.986점 (100점 만점), 자아존중감은 평균 3.873점(5점 만점)으로 100점 으로 환산하면 77.46점이다. 여드름 발생 원인의 경우 초등학교 의 경우가 가장 인식이 낮았으며, 중학교, 고등학교 순으로 나타 났다. 여드름 관리에서는 초등학교와 중학교는 차이가 없었으나, 초등학교 · 중학교 보다는 고등학교에서 인식이 높았다. 마지막으 로 여드름 악화 요인에서는 초등학교가 가장 악화 요인에 대한 인 식도가 낮았으며, 중학교, 고등학교 순으로 나타났다. 즉 재학 학 교 급이 올라갈수록 여드름 인식도가 높아지는 것으로 나타났다. 
Table 7. Acne awareness and self-esteem analysis

\begin{tabular}{|c|c|c|c|c|c|c|c|}
\hline Factor & Level of school & Average & SD & $\mathrm{N}$ & $F$ & $p$ & Scheffe \\
\hline \multirow{3}{*}{ Causes of acne } & Elementary school (a) & 52.922 & 15.241 & 65 & \multirow{3}{*}{23.798} & \multirow{3}{*}{$0.000^{* * *}$} & \multirow{3}{*}{$\mathrm{a}<\mathrm{b}<\mathrm{c}$} \\
\hline & Middle school (b) & 59.416 & 14.165 & 177 & & & \\
\hline & High school (c) & 67.397 & 16.198 & 153 & & & \\
\hline \multirow{3}{*}{ Acne skin care } & Elementary school (a) & 67.898 & 16.183 & 65 & \multirow{3}{*}{5.923} & \multirow{3}{*}{$0.003^{* * *}$} & \multirow{3}{*}{$a, b<c$} \\
\hline & Middle school (b) & 68.155 & 13.871 & 177 & & & \\
\hline & High school (c) & 73.302 & 14.919 & 153 & & & \\
\hline \multirow{3}{*}{ Acne-worsening factors } & Elementary school (a) & 73.788 & 19.672 & 65 & \multirow{3}{*}{12.049} & \multirow{3}{*}{$0.000^{* * *}$} & \multirow{3}{*}{$\mathrm{a}<\mathrm{b}<\mathrm{c}$} \\
\hline & Middle school (b) & 80.397 & 18.372 & 177 & & & \\
\hline & High school (c) & 86.603 & 17.702 & 153 & & & \\
\hline \multirow[t]{2}{*}{ Acne awareness sum } & & 69.986 & & & & & \\
\hline & Elementary school & 3.846 & 0.699 & 65 & \multirow{3}{*}{0.751} & \multirow{3}{*}{0.473} & \multirow{3}{*}{$\mathrm{N} / \mathrm{A}$} \\
\hline \multirow[t]{2}{*}{ Self-esteem } & Middle school & 3.939 & 0.715 & 175 & & & \\
\hline & High school & 3.834 & 0.935 & 142 & & & \\
\hline Self-esteem sum & & 3.873 & & & & & \\
\hline
\end{tabular}

Missing values, acne awareness $(n=1)$, self-esteem $(n=14)$.

$\mathrm{SD}$, standard deviation; ${ }^{* * *} p<0.001$.

Table 8. Correlation between acne awareness and self-esteem

\begin{tabular}{|c|c|c|c|c|}
\hline Division & Causes of acne & Acne skin care & $\begin{array}{l}\text { Acne-worsening } \\
\text { factors }\end{array}$ & Self-esteem \\
\hline Causes of acne & 1 & & & \\
\hline Acne skin care & $0.401^{* *}$ & 1 & & \\
\hline Acne-worsening factors & $0.469^{* *}$ & $0.393^{* *}$ & 1 & \\
\hline Self-esteem & $0.121^{*}$ & $0.118^{*}$ & $0.119^{*}$ & 1 \\
\hline
\end{tabular}

인천지역 남 - 여 고등학생을 대상으로 연구한 Ham et al. (2009)에서는 남성 4.72점, 여성 6.19점으로 여성이 남성보다 여드름에 대한 인식이 높게 나타났으며, Won (2009)의 연구에 서 남학생은 유의하지 않았으나 여학생은 재학 학교 급에 따라 여드름 등급과 여드름에 대한 상식 $(\mathrm{r}=0.161 ; p<0.05)$ 과 정적 상 관관계를 보여주었고 $\mathrm{Oh} \& \mathrm{HeO}$ (2008)은 여고생들의 인식도는 64.8점이며 재학 학교 급이 올라 갈수록 인식도가 높아져 본 연 구의 결과와 유사하였다.

선행 문헌과 본 연구를 통해 여드름 인식도는 성별, 연령, 지 역 등에 따라 달리 나타났으며 여드름 유병율이 높은 것에 비해 인식도는 낮았다. 이는 개인적인 관리를 잘못하여 흉터를 남길 수 있는 소지가 있으므로 이러한 문제를 해결하기 위해서 청소년 에게 여드름 피부에 대한 올바른 정보를 제공하여 여드름 인식도 를 높일 필요가 있다.

\section{6. 여드름 인식도와 자아존중감의 상관관계 분석}

Table 8은 상관관계를 분석한 것으로 여드름 인식도인 여드름 발생원인(r=0.121) 여드름 관리( $\mathrm{r}=0.118)$ 및 여드름 악화 요인 $(\mathrm{r}=0.119)$ 모두 자아존중감에 정 $(+)$ 의 상관관계로 나타났다.

여드름과 자아존중감의 상관관계 연구로는 Dang (2013) 및 Noh \& Jung (2014) 등에서 청소년의 여드름의 유·무 정도가 심리적으로 민감한 청소년기의 학업 및 대인관계, 자아존중감 등 에 좋지 않은 영향을 미치는 것으로 보고된 바가 있다. 여드름이 자아존중감에 부(-)의 영향을 주는 연구가 있는 반면 Kim et al. (2008)은 여성노인을 대상으로 8주간 미용 교육 프로그램을 받 은 실험군에서 자아존중감이 향상되는 것으로 연구되었다. 따라 서 본 연구의 여드름 인식도는 미용 교육의 일부로 자아존중감에 정 $(+)$ 의 상관관계를 뒷받침 해준다.

\section{7. 여드름 인식도가 자아존중감에 미치는 영향 분석}

Table 9에서는 여드름 인식도가 자아존중감에 미치는 영향을 살펴본 결과로서, 모형의 설명력은 $3.2 \%$ (adjust $R^{2}=0.024$ )로 나 타났고 유의한 모형으로 나타났다. 독립변수가 종속변수에 미치 는 영향을 살펴보면 여드름 관리에 대한 인식, 여드름 악화 요인 에 대한 인식이 자아존중감에 정(+)의 영향을 미치는 것으로 나 타났다. 여드름 관리에 대한 인식이 1 증가할 경우 자아존중감이 
Table 9. Effects of acne awareness on self-esteem

\begin{tabular}{llccrcccc}
\hline Dependent variable & Independent variable & $\mathrm{B}$ & $\beta$ & $t$ & $p$ & $\mathrm{R}^{2}$ & adj. $\mathrm{R}^{2}$ & $F$ \\
& (Constants) & 4.459 & & 24.889 & $0.000^{* * *}$ & & & \\
\multirow{3}{*}{ Self-esteem } & Causes of acne & 0.130 & 0.073 & 1.018 & 0.309 & 0.032 & 0.024 & 4.110 \\
& Acne skin care & 5.156 & 0.650 & 38.472 & $0.000^{* * *}$ & & & \\
& Acne-worsening factors & 4.040 & 0.620 & 22.421 & $0.000^{* * *}$ & & & \\
\hline
\end{tabular}

$\mathrm{B}$, unstandardized coefficients (partial regression coefficient); $\beta$, standardized coefficient (influence); $\mathrm{R}^{2}$, $\mathrm{R}$ square (coefficient of determination); adj. $\mathrm{R}^{2}$, adjusted $\mathrm{R}$ square; ${ }^{* * *} p<0.001$.

0.650 만큼 증가하는 것으로 나타났으며, 여드름 악화 요인에 대한 인식이 1 증가할 경우 자아존중감이 0.620 만큼 증가하는 것으로 나타났다.

여드름과 정신 건강과의 관련성을 연구한 Lee (2006)의 연구 에서 여드름이 있는 경우 대인예민성과 정신증에 부정적인 영향 을 주고, 지속 기간이 길수록 강박증, 우울, 불안, 적대감 등 모 든 영역에 부정적인 영향을 주는 것으로 발표하였으며 Kim \& $\operatorname{Kim}$ (2016)은 청소년의 외모만족도가 자아존중감과 외모관리행 동에 미치는 영향을 연구하여 외모만족도가 높으면 가정적 자아 존중감과 사회적 자아존중감이 높아지는 것으로 발표하였다. 이 는 신체 외모가 자아존중감에 영향을 미친다는 기존의 연구를 뒷 받침하는 결과로 청소년기에 발생하는 여드름의 부정적인 측면 을 간과해서는 아니 된다. 이에 본 연구는 미용 교육의 한 분야인 여드름의 인식도가 자아존중감에 정( +$)$ 의 상관관계가 있는 것으 로, 이는 청소년의 여드름 발생 시 관리 방법 및 악화 요인을 인 식하였을 때 피부 관리 시 적절히 대처함으로써 여드름의 상태 가 개선될 것이라는 심리적 안정감과 신뢰감을 줄 수 있는 것으 로 사료된다. 따라서 본 연구의 결과는 청소년을 대상으로 여드 름 인식 교육을 통해 자아존중감 향상에 기여할 수 있다는 것을 의미하므로 피부 미용 교육의 필요성이 더욱 절실하다.

\section{Conclusion}

본 연구는 청소년의 여드름 특성을 연구하고 여드름 인식도와 자아존중감의 상관관계를 알아보기 위해 설문 조사를 실시하여 다음과 같은 결과를 얻었다.

연구 대상자의 인구학적 특성으로 초등학교 $16.4 \%$ (65명), 중 학교 $44.7 \%$ (177명) 및 고등학교 $38.9 \%$ (154명)이다. 학년별 로는 고등학교 1학년(20.2\%), 중학교 2학년(17.9\%), 중학교 1 학년(17.2\%), 고등학교 2학년(15.4\%), 초등 5 학년(11.6\%) 순이 며 연구 대상자의 피부 유형은 복합성 $(27.6 \%)$ 이 가장 많고 건성 (26.6\%), 중성(17.0\%), 지성(13.7\%), 잘 모르겠다(10.6\%), 민 감성 $(4.6 \%)$ 순으로 복합성과 건성의 피부 유형이 과반 이상이 다.
연구 대상 청소년의 여드름 유병율은 초등학교 $(56.9 \%)$, 중학 교(82.5\%), 고등학교(90.3\%)로 전체 $81.3 \%$ 로 조사되었으며, 발생 학년은 초등학교 고학년 $(5,6$ 학년) $37.0 \%$ 가장 많고 다음 으로 중학교 1학년 $26.4 \%$, 중학교 2학년 $16.8 \%$, 중학교 3학년 $9.3 \%$, 고등학교 1학년 9.0\%, 고등학교 2학년 $1.2 \%$ 순으로 많이 발생하였다. 또한 피부 유형별 여드름 발생은 복합성과 지성 피 부가 여드름의 발생 비율이 높게 나타났으며(96.3\%), 특히 건성 (80.0\%)과 민감성(77.8\%)도 여드름 발생 비율이 높기 때문에 기 초 화장품 위주의 사용과 저자극 세안제 및 보습 위주의 관리가 필요한 것으로 나타났다.

연구 대상 청소년은 전반적으로 경미한 면포와 구진의 여드름 으로 중학교 이상부터는 구진의 비율이(중학교 $31.5 \%$, 고등학교 $30.9 \%)$ 높아지고, 결절은 고등학교에서 $18.0 \%$ 로 가장 높아 학 년이 증가할수록 등급이 높아지는 경향이 있었다. 또한 건성, 중 성, 복합성 및 민감성의 피부 유형의 경우는 면포가 많고 지성은 구진의 비율이 높은 것으로 나타났다. 이에 따라 대다수 학생들 이 주된 피부 고민으로 여드름을 꼽았으며(초등학교 $30.8 \%$, 중 학교 $38.4 \%$, 고등학교 $47.4 \%$ ), 학년이 증가할수록 모공(초등 학교 $13.8 \%$, 중학교 $19.2 \%$, 고등학교 $31.8 \%$ ) 및 유분(초등학 교 $3.1 \%$, 중학교 $14.1 \%$, 고등학교 $16.2 \%$ ) 등의 관심 정도가 증 가하는 것으로 나타났다. 한편 피부 유형별 피부 고민으로는 건 성 피부 유형의 경우 건조함, 지성 피부의 경우 모공, 복합성 피 부의 경우 모공을 여드름 다음으로 고민으로 느끼고 있는 것으로 나타났다.

본 연구에서 여드름의 인식도와 자아존중감의 상관관계를 분 석한 결과로 대상 청소년의 여드름 인식도는 평균 69.986 점 (100점 만점)이고 자아존중감은 평균 3.873점(5점 만점)으로서 백점으로 환산하면 77.46점으로 나타나 여드름 유병율에 비해 여드름 인식도가 낮은 것으로 여드름 발생 시 피부 관리에 적절 히 대처하지 못하는 것으로 나타났다. 또한 여드름 인식도인 여 드름 발생 원인과 여드름 관리 및 악화 요인의 경우 초등학교가 가장 낮고 중학교, 고등학교 순으로 인식이 높게 나타났다. 한편 여드름 인식도와 자아존중감의 상관관계를 확인한 결과 정 $(+)$ 의 상관관계가 있는 것으로 나타났다. 아울러 여드름 인식도가 자 아존중감에 미치는 영향을 살펴본 결과 모형의 설명력은 $3.2 \%$ 
(adjust $R^{2}=0.024$ )로 나타나 여드름 인식도가 자아존중감의 여 러 요소 중 $3.2 \%$ (수정된 설명력 2.4\%)를 차지하는 것으로 평가 되었다. 따라서 여드름 관리에 대한 인식이 1 증가할 경우 자아 존중감이 0.650 만큼 증가하는 것으로 나타났으며, 여드름 악화 요인에 대한 인식이 1 증가할 경우 자아존중감이 0.620만큼 증 가하는 것으로 나타났다. 이는 여드름 발생 시 원인과 관리 방법 및 악화 요인을 알고 적절히 대응함으로써 심각한 여드름의 악화 진행을 방지하게 되고 여드름 화장품 사용 방법이나 여드름 관리 에 대한 사전 교육은 청소년에게 2 차 병변이나 후유증으로 발전 되는 것을 막아 여드름 예방에 도움이 될 것이라는 심리적 안정 감과 신뢰감을 줄 수 있는 것으로 자아존중감에 긍정적 영향을 미치는 것으로 판단되었다. 따라서 여드름이 초등학교 고학년에 서부터 발생하고 있는 상황에서, 초기에 적절히 대처함으로써 악 화를 방지하고 흥터를 예방할 수 있도록 청소년을 대상으로 한 피부 미용 교육 프로그램에 대한 필요성이 절실한 실정이다.

본 연구는 초등학생, 중학생, 고등학생 여학생 전체를 대상으 로 여드름 특성을 비교 연구되었으며, 여드름 인식도가 자아존 감과 정(+)의 상관관계가 있음을 확인한 연구로서 그 의의가 있 다. 그러나 조사 대상이 수도권 내 서울시, 화성시, 수원시로 한 정되어 있어 일반화하기에는 무리가 있으므로 향후 조사에서는 대상 범위를 확대할 필요가 있다.

This work is part of Ok-Sun Jang's M.S. thesis at Kwangwoon University, Seoul, Korea.

\section{References}

Ahn BK, Lee SJ, Namkoong K, Chung YL, Lee SH. Quality of life of acne patients. Korean Journal of Dermatology, 43: 6-14, 2005.

Dang SM. Effect of acne in female high school students on their mental health and stress. Journal of Investigative Cosmetology, 9: 137-141, 2013.

Goulden V, McGeown CH, Cunliffe WJ. The familial risk of adult acne: a comparison between first-degree relatives of affected and unaffected individuals. British Journal of Dermatology, 141: 297-300, 1999.

Ham MO, Kim BY, Back SY, Seo MJ. A study on the recognition survey of acne for high school boy $\&$ girl. Journal of the Korean Society of Esthetics \& Cosmeceutics, 4: 27-38, 2009.

Kang MJ, Hahm JH. Comparative study of acne on clinical features and patient understandings in adolescence and post-adolescence. Korean Journal of Dermatology, 38: 589-599, 2000.

Katsambas AD, Stefanaki C, Cunliffe WJ. Guidelines for treating acne. Clinics in Dermatology, 22: 439-444, 2004.

Kim BK, Park CM, Do JD. A beauty program's effect on female senior citizens. Journal of the Korean Society of Cosmetology, 14: 266-273, 2008.

Kim HO, Lee YS. The epidemiology and patient understandings of adolescence acne in Korean high school students. Journal of the Korean Society of Cosmetology, 15: 399407, 2009.

Kim JD. A study on skin care and prevention of acne. Journal of the Korean Society of Cosmetology, 1: 101-117, 1995.

Kim KO, Cha YA. The relation of acne state and the emotional impact in adolescence. Journal of the Korean Society of Cosmetology, 5: 369-384, 1999.

Kim KO, Cha YA. The research of degree of acne and related factor, the control method for adolescence. Journal of the Korea Higher Vocational Education Association, 1: 131-138, 2000.

Kim SH, Kim EH. A study of the effects of appearance satisfaction on self-esteem and appearance management behavior in adolescents. Journal of the Korean Society of Cosmetology, 22: 1275-1285, 2016.

Kubota Y, Shirahige Y, Nakai K, Katsuura J, Moriue T, Yoneda K. Community-based epidemiological study of psychosocial effects of acne in Japanese adolescents. The Journal of Dermatology, 37: 617-622, 2010.

Lee SH, Park TH, Kang WH, Whang KK, Lee CW, Sung KJ, Ahn SK, Park JK. A statistical analysis of acne patients who visited university hospitals recently. Korean Journal of Dermatology, 34: 386-393, 1996.

Lee SH, Park TH. Current review of acne. The Korean Journal of Aerospace and Environmental Medicine, 6: 57-64, 1996.

Lee TS. The effects of adolescents' acne on the mental health. Journal of the Korean Society of Esthetics \& Cosmeceutics, 1: 111-118, 2006.

Na MS, Ju EH, Kim MH. A study on pimple break out and influencing factors in middle school students. Asian Journal of Beauty and Cosmetology, 7: 153-163, 2009.

Noh HR, Jung SM. 10 Adolescent acne is about the impact on quality of life research. Asian Journal of Beauty and 
Cosmetology, 12: 339-344, 2014.

Oh HY, Heo SD. A study of high school girls' awareness of acne. Journal of the Korean Society of Cosmetology, 14: 124-133, 2008.

Paek HY, Kim JD. A study of survey and knowledge of acne. Journal of Korean Society of Cosmetology, 15: 910-920, 2009.

Park MK, Dang YS. The influence that breaking out pimple effects to mental health of some high school girls. The Journal of Korea Beauty Design Society, 4: 265-273, 2008.

Poli F, Auffret N, Beylot C, Chivot M, Faure M, Moyse D, Pawin H, Revuz J, Dréno B. Acne as seen by adolescents: results of questionnaire study in 852 French individuals. Acta Dermato-Venereologica, 91: 531-536, 2011.

Shin HW, Ko JY, Ro YS. A statistical analysis of the epidemiology, clinical features and perceptions of acne in middle school students in Seoul Seongdong area. Korean Journal of Dermatology, 47: 154-163, 2009.

Shin KH, Lee HS, Kim KC. Sebum creation and acne. The Journal of Skin Barrier Research, 10: 56-60, 2008.

Shin S. Acne vulgaris in Korean adolescence. Korean Journal of Dermatology, 11: 17-27, 1973.

Won YK. Study on characteristics of adolescent acne in Chung Cheong area. Asian Journal of Beauty and Cosmetology, 7: 161-174, 2009.

Wu TQ, Mei SQ, Zhang JX, Gong LF, Wu FJ, Wu WH, Li J, Lin M, Diao JX. Prevalence and risk factors of facial acne vulgaris among Chinese adolescents. International Journal of Adolescent Medicine and Health, 19: 407-412, 2007. 


\section{국문초록}

\section{청소년기 여드름 인식도와 자아존중감의 상관관계}

장옥선, 박안나

광운대학교 정보콘텐츠대학원 미디어뷰티아트과, 서울, 한국

목적: 청소년기 여학생의 여드름 피부 특성을 조사하여 여드름 인식에 따른 자아존중감에 대한 상관관계 분석을 통해 청소년을 대 상으로 한 피부 미용 교육의 필요성에 대한 자료를 마련하기 위함이다. 방법: 2016년 12월 1일부터 24일까지 설문조사를 실시하여 총 396부를 빈도 분석, 교차 분석, 신뢰도 분석, 일원배치분산 분석, 다중 회귀 분석의 통계 방법으로 분석하였다. 결과: 본 연구의 대상자는 초등학생(16.4\%), 중학생 $(44.7 \%)$, 고등학생(38.9\%)이다. 청소년의 여드름 발생 경험은 초등학생(56.9\%), 중학생(82.5\%), 고등학생 $(90.3 \%)$ 순이며 발생 시기는 초등학교 고학년(37.0\%)에서 가장 많이 발생하였다. 전반적으로 여드름의 형태는 면포형이 주를 이루었으나, 고학년일수록 여드름 등급이 높아지는 것으로 분석되었다. 여드름 인식도는 학년 급이 올라 갈수록 인식도가 높 아졌다. 상관관계 분석 결과 여드름 발생 원인, 여드름 관리, 여드름 악화 요인 모두 자아존중감에 정(+)의 관계로 확인되었다. 또한 여드름 발생 원인을 제외한 여드름 관리 및 여드름 악화 요인은 자아존중감에 정 $(+)$ 의 영향을 미치는 것으로 분석되었다 $(p=0.000$; $R^{2}=0.032$; adj. $R^{2}=0.024$; 여드름 관리 $\beta=0.650$; 여드름 악화요인 $\left.\beta=0.620\right)$. 결론: 본 연구는 청소년이 여드름 관리와 여드름 악 화요인을 인식하는 것이 자아존중감에 정(+)의 영향을 미친다는 것을 확인한 점에서 의의가 있었다. 따라서 생리적인 변화를 경험 하는 청소년기 여학생에 대하여 피부 생리학적으로 화장품의 사용 및 여드름 피부 관리 방법 등의 피부 미용 교육이 필요한 것으로 사료된다.

핵심어: 청소년, 여드름, 피부 미용, 인식도, 자아존중감

\section{참고문헌}

강민정, 함정희. 청소년기와 성인기 여드름의 임상 양상 및 여드름에 관한 인식도의 비교 분석. 대한피부과학회지, 38 : 589-599, 2000.

김광옥, 차영애. 청소년들의 여드름 등급 및 관련요인과 관리방법에 관한 연구. 한국고등직업교육학회논문집, $1: 131-$ 138, 2000.

김광옥, 차영애. 청소년의 여드름과 정서상태와의 관련성 연구. 한국미용학회지, $5: 369-384,1999$.

김보경, 박천만, 도종두. 여성노인에 대한 미용교육 프로그램의 효과. 한국미용학회지, 14: 266-273, 2008.

김선형, 김의형. 청소년의 외모만족도가 자아존중감과 외모관리행동에 미치는 영향. 한국미용학회지, $22: 1275-1285$, 2016.

김종대. 여드름의 피부관리 및 예방에 관한 연구. 한국미용학회지, 1: 101-117, 1995.

김현옥, 이영숙. 한국 고등학생에서 청소년기 여드름의 역학 및 여드름에 대한 인식도에 관한 연구. 한국미용학회지, $15:$ 399-407, 2009.

나명순, 주은하, 김미혜. 중학생들의 여드름 발생요인에 관한 연구. 아시안뷰티화장품학술지, $7: 153-163,2009$.

노혜란, 정소명. 10 대 청소년기의 여드름이 삶의 질에 미치는 영향에 대한연구. 아시안뷰티화장품학술지, $12: 339-344$,

2014

당수민. 여드름이 여고생들의 정신건강과 스트레스에 미치는 영향. 대한미용학회지, 9: 137-141, 2013.

박미경, 당영숙. 일부 여고생의 여드름 발생상태가 정신건강에 미치는 영향. 코리아뷰티디자인학회지, 4: 265-273, 2008.

백혜연, 김주덕. 여드름의 실태 및 인식에 관한 연구. 한국미용학회지, 15: 910-920, 2009. 
신경훈, 이혜숙, 김관철. 피지 생성과 여드름. 한국피부장벽학회지, 10: 56-60, 2008.

신실. 한국인(韓國人) 청소년(靑少年)에 발생(發生)하는 좌창(座瘡)에 관(關)한 통계적(統計的) 고찰(考察). 대한피부과학회 지, 11: 17-27, 1973.

신혜원, 고주연, 노영석. 서울 성동지역 중학생에서의 여드름의 역학과 임상적 특성 및 인식도에 대한 통계적 고찰. 대한피 부과학회지, 47: 154-163, 2009.

안봉균, 이상주, 남궁기, 정예리, 이승헌. 여드름 환자의 삶의 질 조사. 대한피부과학회지, 43: 6-14, 2005.

오혜영, 허순득. 여고생들의 여드름 인식에 대한 연구. 한국미용학회지, 14: 124-133, 2008.

원윤경. 충청지역 청소년의 여드름 특성에 관한 연구. 아시안뷰티화장품학술지, 7: 161-174, 2009.

이승헌, 박태현, 강원형, 황규광, 이창우, 성경제, 안성구, 박장규. 최근 병원 내원 여드름 환자의 통계적 고찰. 대한피부과 학회지, 34: 386-393, 1996.

이승헌, 박태현. 여드름의 최신지견. 항공우주의학회지, 6: 57-64, 1996.

이태숙. 청소년의 여드름이 정신건강에 미치는 영향. 한국피부미용향장학회지, 1: 111-118, 2006.

함명옥, 김보영, 백선영, 서민지. 여드름에 대한 남 - 여 고등학생들의 인식도 조사. 한국피부미용향장학회지, 4: 27-38, 2009. 


\section{中文摘要}

\section{青少年期痤疮认知度与自尊的相关关系}

張玉仙 ${ }^{*}$, 朴安羅

光云大学校情报CONTENTS大学院传媒美容艺术科，首尔，韩国

目的: 通过调查青春期女孩的痤疮皮肤特征, 根据痤疮认知与自尊的相关性分析, 提供了关于青少年皮肤美容 教育的必要性的数据。方法: 从2016年12月1日至12月24日进行了问卷调查, 共对396份调查资料利用频率分 析、交叉分析、可靠性分析、单向方差分析（ANOVA）和多元回归分析等统计方法进行分析。结果：这项研 究的对象是小学生 (16.4\%) 、中学生 $(44.7 \%)$ 和高中生 $(38.9 \%)$ 。青少年发生过痤疮的按百分比小学生 (56.9\%) 、中学生（82.5\%）和高中生（90.3\%）顺序发生。发生时期在小学高年级中最常见（37.0\%）。痤 疮最常见的形式是comedos ; 然而, 痤疮的程度往往随着高年级有所增加。痤疮的意识也随着高年级增加。相 关分析证实, 痤疮发生原因, 痤疮皮肤护理和痤疮恶化因素与自尊正相关。此外, 除痤疮的发生原因外, 痤疮 皮肤护理和痤疮恶化因素对自尊有正面影响 $\left(p=0.000 ; \mathrm{R}^{2}=0.032 ; \mathrm{R}^{2}=0.024\right.$; 痤疮皮肤护理 $\beta=0.650$; 痤疮恶 化因子 $\beta=0.620 ） 。$ 结论: 这项研究确认了痤疮皮肤护理和痤疮恶化因素的认知对自尊有积极影响, 因此具有 意义。对于正在经历生理变化的青少年女孩, 应该提供皮肤护理的生理教育, 如适当使用化妆品和治疗痤疮。

关键词: 青少年, 痤疮, 皮肤美容, 认知度, 自尊 
